\title{
The relation of master and disciple against the background of Józef M. Bocheński's logic of authority
}

\author{
Tomasz Kubalica ${ }^{1}$ iD
}

Accepted: 13 September 2021 / Published online: 25 October 2021

(c) The Author(s) 2021

\begin{abstract}
The aim of this article is to apply Józef M. Bocheński's logic of authority to a key interpersonal relation of philosophical interest: the master-disciple relation. The present research addresses the problem of philosophical authority in terms of the assumptions of the logic of authority and its consequences for philosophical historiographical research and verifies the claims of the logic of authority in this respect. The analyses show that, in the field of philosophy, the axiological authority of the master plays a fundamental role and is not limited solely to epistemic or deontic authority.
\end{abstract}

Keywords Relation of master and disciple $\cdot$ Logic of authority · Józef M. Bocheński

\section{Paper}

This paper presents the results of research on Józef M. Bocheński's logic of authority applied to a basic interpersonal relation described in the history of philosophy: the master-disciple relation. The problem of basic interpersonal relations among/ between philosophers is important for the methodology of the history of philosophy because it concerns the very object of historical-philosophical research (Kubalica, 2019). ${ }^{1}$ The motive for the present analysis is the belief underlying the practice of historical-philosophical research and often justified in studies on the methodology of the history of philosophy, viz. taking a selective approach to historical-philosophical material (selectivity). The result of a selective approach is a false image of the history of philosophy dominated by the names of outstanding philosophers. Such a model is indiscriminately reproduced in popular books on the history of

\footnotetext{
${ }^{1}$ The logic of the master-disciple relationship was presented on the example of Hermann Cohen and Ernst Cassirer in my recent article (Kubalica, 2019). In this paper, I present conclusions from further research on classical examples from the history of philosophy.
}

Tomasz Kubalica

tomasz.kubalica@us.edu.pl

1 University of Silesia in Katowicw, Katowice, Poland 
philosophy. For example, Volume 4 of Copleston's history includes five chapters on Descartes, followed by sections on Pascal, Cartesianism and Malebranche, five chapters on Spinoza and four on Leibniz (Copleston, 1994, p. VII-IX). This volume is a prime example of a source purveying an entirely untrue view that presents distinguished philosophers isolated from the historical background and trends created by them. After all, we know that this picture is not true, and that many other lesser-known figures influenced the main ideas of philosophers such as Descartes. The point is, above all, that philosophy develops in a historically defined complex network of biographical, bibliographical and doxographic relations. Therefore, it is not only essential matters such as the terms and ideas proposed by philosophers that play an integral role in this process. This historical development of philosophy consists ultimately in asking questions and giving answers.

The point is that collective forms of philosophical activity are not uniform in nature and differ primarily in the degree of unity within a particular group (Kubalica, 2015, p. 55). The most united are religious-philosophical communities, such as the Pythagoreans. A lesser degree of community characterises philosophical schools such as the Academy of Plato or Lyceum of Aristotle. Further, there are the Renaissance disciples who, centuries later, refer to the ideas of earlier philosophers such as the Aristotelians and Averroists in the Middle Ages. Although the degree of community of views in these philosophical groups varies, it is worth noting that all are based on one model, viz. the relation of authority between master and disciple. In the Pythagorean setting, the master was the mythical Pythagoras, with whom all members of the community identified to such an extent that they did not use their own names, but only his. Although a lesser degree of consistency characterises the schools of Plato or Aristotle, the relation of authority is evident here too. Likewise, we see authority relations, albeit with less intensity, in the continuation of old ideas adapted to another time and place.

What is needed is a logically coherent model of these relations, at least regarding the three basic lines of research in the history of philosophy, namely (1) elaboration of biographical, bibliographical and doxographic data, (2) systematisation of philosophical terms and ideas, and (3) study of erotetic relations of questions to answers. Literature on the methodology of the history of philosophy focuses mainly on such basic aspects as the object and methods of practicing the history of philosophy (Gogacz, 1964, 1966; Swieżawski, 2005). However, what is lacking is reflection on such salient categories as the influence of authority that historians of philosophy appeal to in their descriptions.

Research has expanded knowledge of philosophical authority in light of the logic of authority and its consequences for philosophical historiography. It has been shown that, in general, the logic of authority can serve as the basis for developing the concept of philosophical authority, useful in philosophical-historiographical research, although with some modifications. Moreover, it has been shown that, contrary to Bocheński's belief, not only deontic authority may be delegated (thesis 8.1); rather, it should be assumed that, at least in philosophy, delegation also applies to epistemic authority.

A classic example of a non-deontic delegation in philosophy is the relation of authority among successive thinkers, such as Socrates, Plato and Aristotle: Socrates 
was the authority for Plato, who became the authority for Aristotle. These relations did not obtain at the same time, of course, because these masters were considered authorities by their disciples not sooner than they became their students. Although not impossible, it is difficult to find in the history of philosophy an example of such a triad coinciding. The history of philosophy, however, reveals the fundamental limitation of the categorical method applied by Bocheński, which is restricted to analysis focused on a single moment on the timeline. We know that authority relations do not just appear at some point, but arise, develop and in time disappear. The problem of the temporal limitation of authority relations is beyond the scope of this discussion and will be left for another occasion.

Bocheński's research on authority does not belong to the field of sociology or psychology; it is not psychosocial, but purely philosophical. It is primarily fundamental research seeking to understand what other sciences simply assume (Bocheński, 1974, pp. 11-12). Bocheński defines this kind of philosophy as analytic philosophy that explores various uses of words in order better to define their meaning. The logic of authority understood in this way is an applied logic dealing with only some of the simplest, but not trivial, aspects of authority. It describes its basic and most general features, starting with "extremely trivial states of affairs (...) that soon give way to things that are by no means trivial" (Bocheński, 1974, p. 13, transl. A. Brożek). Bocheński describes the so-called semiotic situation of authority, or, more precisely, its pragmatic situation in the sense of Charles W. Morris' logical pragmatics. On this understanding, pragmatics is a part of semiotics which captures the relation between verbal signs and their interpreters (sender and receiver). In any case, the logic of authority, so understood, does not mean for Bocheński a complete account of the problem, which would have to include psychology, sociology and other sciences as well.

The main result of this research is the conclusion that, contrary to Bocheński's claim, epistemic authority may also be delegated in academic-scholarly relations between the master and disciple. The most important achievement of Bocheński's study is the distinction between two types of authority-epistemic and deonticbased on a purely logical analysis (Brożek, 2013). In his view, each authority can be identified as epistemic or deontic (4.2), which he explains in the following way:

Die epistemische Autorität ist nämlich jene des Menschen, der besser, mehr weiß als das Subjekt. So ist z.B. die Autorität des Lehrers für einen Studierenden eine epistemische. Es ist die Autorität des Sachverständigen. Dagegen ist die deontische Autorität nicht jene des besser Wissenden, sondern sie gehört dem Vorgesetzten, dem Chef, dem Kommandeur, dem Leiter usw.

[Epistemic authority accrues to the individual who knows better, knows more than the subject. For example, the teacher's authority for a student is epistemic. It is the authority of the expert. The deontic authority, on the other hand, is not that of whoever knows more and better, but that of the superior, the boss, the commander, the leader, etc.]. (Bocheński, 1974, p. 53; all translations mine)

Epistemic authority and deontic authority, even if they refer to the same person, indicate two different but closely related fields. The domain of deontic authority is 
a class of directives, while the domain of epistemic authority is constituted by corresponding practical sentences (Bocheński, 1974, p. 53; Kubalica, 2020, pp. 58-59). Both types of authority are not mutually exclusive (4.3); on the contrary, it is desirable for the bearer of deontic authority to be at the same time the bearer of epistemic authority in the relevant field (4.4). The most important thing is that the two types of authority are independent, i.e., having epistemic authority does not entail having deontic authority (4.5) and, in particular, the bearer of deontic authority does not have to be an epistemic authority in the relevant field (Bocheński, 1974, p. 54).

It is important to understand the concept of epistemic authority which from the outset excludes the possibility of formulating directives. For Bocheński, the bearer of such authority is "not a superior, and so he cannot and should not instruct the subject on how he should act, but he offers him statements" (Bocheński, 1974, p. 57). This means that the bearer of epistemic authority cannot give advice, guidelines or recommendations to the subject of authority if they take the form of directives that define the principles of action, the type of behaviour, the procedure, the plans for the implementation of a specific project or even instructions concerning the implementation of a specific action. It is not easy to find a situation where Bocheński allows for the possibility of combining epistemic and deontic authority. Bocheński's position is incompatible with the ethical intellectualism of Socrates and Plato (Bocheński, 1974, p. 77); he opposes the idea that philosophers should have political power. Thus, Bocheński proposed a very narrow definition of epistemic authority, which in this narrow sense is incompatible with the notion of master, because it is the role of the master to give specific recommendations, also of a normative nature. The concept of master combines epistemic and deontic authority. Let us examine the extent to which the two concepts of authority coincide.

A master is a distinguished person who achieves the highest level of knowledge or skill in a particular field, who is an authority and a role model. A master can be both a superior, for instance, of an association or a knightly order (deontic authority), as well as a professional, for instance, a certified craftsman (epistemic authority). However, the notion of master is broader than authority because it can also refer to a winner in a competition whom we admire and respect, but we do not obey his commands or recognise his knowledge, as in the case of deontic and epistemic authority. Therefore, we distinguish between a master in a broad and narrow sense.

The concept of master is one of the two components in the conceptual relation between the master and disciple; it implies complementarity with the concept of disciple and vice versa. The concept of the master is understood narrowly here and presupposes direct contact between master and disciple and a mutual acceptance of this relationship. Władysław Stróżewski describes the complex master-disciple relation by pointing to its individual and unique character and emphasising its formative function (Stróżewski, 1996). At the same time, he points out certain characteristic features of this relation, such as shaping attitudes and ways of conduct by way of the master's presence to the students, contributing to an atmosphere of freedom of opinion and decision without the master's imposition, as well as expressing the desire to help the students. Among the properties of the master-disciple relation mentioned by Stróżewski, the most important is the axiological transfer of the hierarchy of values professed by the master, in particular regarding the importance of 
scholarly work. In this context, the unquestionable epistemic authority of the master reveals an additional dimension: not only deontic but also axiological. The master is not only an epistemic and deontic authority, but above all, an axiological one. This means that apart from the notion of authority, references to values, such as truth, should be added to the bearer-subject relations described by Bocheński within the logic of authority.

The master in the sense of historical-philosophical relations can be identified with authority in the sense given by Bocheński:

T ist eine epistemische Autorität für S im Gebiet G genau dann, wenn S prinzipiell jeden Satz anerkennt, der ihm mit Behauptung von $\mathrm{T}$ mitgeteilt wird und zum Gebiet $\mathrm{G}$ gehört.

[T is an epistemic authority for $S$ in area $G$ if and only if $S$ in principle recognises as true every statement that $\mathrm{T}$ assertively communicates to him and belongs to area G.]. (Bocheński, 1974, p. 57)

The authority of the master is not absolute. An example is the classic relation between Plato and Aristotle. The former was only a master teacher for the latter, until the pupil surpassed the master. At the age of 18, Aristotle was sent to Athens to receive his education at Plato's Academy (Ross, 2004, pp. 1-2). At the Academy, Aristotle spent a total of 19 years, during which he was first a student, then Plato's assistant and finally a teacher himself. Plato had a formative influence on Aristotle, although the latter departed from the master's doctrine in his mature years. On the one hand, this means that the master's competence determines the extent of his or her authority. On the other hand, it shows that the authority relation changes as the student's competence increases until the student questions the master's authority. The bearer loses the authority of the master when he or she is incompetent. When the subject of the master's authority believes that he or she knows more about a given field than the authority he or she has recognised so far, the relation of authority disappears.

In this context, Stróżewski draws attention to the personal dimension of authority recognition, which consists not only in recognising every statement made by the subject of authority as true, as Bocheński puts it, but also in recognising the bearer as an authority by its subject, stressing that "without social recognition, becoming an authority is not possible" (Stróżewski, 1992, p. 33). Therefore, "professionalism" alone is not enough to establish authority; what is needed is reference to certain moral values, as each authority implies the presence of values: truth and responsibility. Bocheński also refers to the truthfulness of the bearer of authority, but for Stróżewski, it implies not only not lying, but also living in truth. The second value element mentioned by Stróżewski concerns responsibility "for the declared truth and for those who await it" (Stróżewski, 1992, p. 33). Although both authors adhere to similar philosophical foundations, this example reveals differences between them: Bocheński understands authority narrowly, while Stróżewski extends its sense.

Acceptance of epistemic authority without justification may be a source of moral abuse, although less frequently than in the case of deontic authority (5.4). People should always act reasonably (Bocheński, 1974, pp. 61-62). This means that the authority of the master must also be justified by reasoning, although the kind of reasoning used 
to justify epistemic authority is necessarily inductive and therefore logically weak (Bocheński, 1974, pp. 63-64).

In this context, the issue of value sentences accepted by the authority becomes significant. Bocheński believes that despite differences in opinions, value sentences are authentic statements, and not directives or orders (Bocheński, 1974, p. 67). Bocheński justifies this position as follows:

Nun genügt es, sie zu analysieren, um festzustellen, daß diese Wertungen alle Kennzeichen der Sätze besitzen. (...) Deshalb scheinen sie Weisungen zu sein. Sie sind jedoch an sich keine Weisungen, sondern Sätze, die eine Grundlage für Weisungen bilden.

[It is now sufficient to analyse them to determine that these valuations have all the characteristics of statements. (...) Therefore, although they seem to be instructions, in fact, they are not; rather, they are statements that form the basis for instructions.]

Consequently, according to Bocheński, it is logically possible for value sentences to fall within the domain of epistemic authority (5.12), for example used by an expert in art or by a moral authority. If, therefore, there are indeed epistemic authorities in the field of value judgments (5.13), there is nothing to prevent the master, as an epistemic authority, from formulating value judgments, unless they are directives. Even in the narrow understanding of the concept, if an epistemic authority can judge a value, then he or she can be an axiological authority. These notions are not contradictory.

The fundamental difference between deontic and epistemic authority is revealed in the delegation of authority. Bocheński concludes that:

Die deontische Autorität, nicht aber die epistemische, kann delegiert werden.

[Deontic authority can be delegated, but epistemic authority cannot]. (Bocheński, 1974, p. 92, 8.1)

This is important for the concept of master set forth here because, on the narrow understanding of the authority of the master, it turns out that its bearer can delegate only deontic authority. However, if one takes into consideration the axiological authority of the master, the question arises of whether this kind of authority can be delegated.

For Bocheński, delegation has a much more complex structure than authority itself (Bocheński, 1974, p. 92) because, apart from the delegating bearer (T), the subject (S) and the domain $(\mathrm{G})$, it also includes the delegated bearer (D) and the delegated domain (F) (8.2). In this way, we obtain a quintuple relation, which implies five quadruple relations, ten ternary relations and ten binary relations, as shown in Fig. 8.21. 


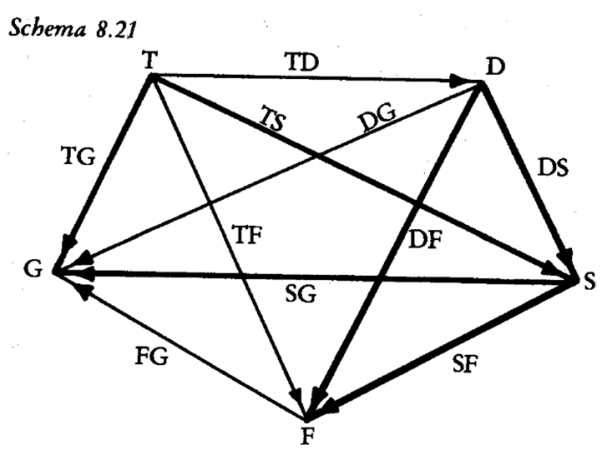

(Bocheński 1974, 94)

The triangles TSG and DSF correspond to the already known basic structure of authority, so we know six out of ten binary relations (TS, TG, SG, DS, DF and SF), and delegation creates the remaining four relations: TD, TF, GD and FG.

If we now refer the relation of delegating authority to the master-disciple relation-assuming that it goes beyond the relation of epistemic authority, which, according to Bocheński, cannot be delegated-we arrive at the following logical consequences that need analysing. The TD relation is fundamental for the structure of delegation and it requires the following actions:

1. Der Hauptträger (der Delegierende) faßt den Entschluß, jemanden als Delegierten zu bestellen. Es handelt sich hier um einen inneren Willensakt, der eine Voraussetzung der Delegation ist, allein aber noch nicht genügt, sie herzustellen.

2. Dazu ist noch eine Mitteilung dieses Entschlusses an dem Delegierten notwendig. Eine solche Mitteilung heißt »Ernennung«: denn durch sie wird der Delegierte gerade zum Delegierten ernannt.

[1. The principal bearer (the one who delegates) decides to appoint someone as a delegate. This is an internal act of will which is a prerequisite for delegation, but which alone is not sufficient to establish it.

2. Communication of this decision to the delegate is necessary. This communication is called "nomination": because it is through it that the delegate is nominated as the delegate]. (Bocheński, 1974, p. 94)

This nomination is a performative act, which, alongside statements and directives, is the third type of autonomous ideal structures ${ }^{2}$; it involves communication of

\footnotetext{
${ }^{2}$ Authority functions in the sphere of communication, which is why Bocheński assumes that its domain does not mean things or events themselves but what is communicated about these events with authority (Bocheński, 1974, pp. 28,29). Consequently, the domain of authority consists of unreal objects because it is about communication of information; not something real, but ideal.
} 
a specific directive to a subject for whom the delegate will be the bearer of authority. It is actually a kind of metadirective, that is, a directive bearing on another directive.

It is not easy to transfer a deontic delegation to an epistemic authority. The question is whether Socrates nominated Plato in this way. Did Plato nominate Aristotle? Plato was one of the many students of the historical Socrates, but the master had such an influence on him that Plato made him the central figure in his dialogues (Kraut, 2006, pp. 2-3, 7). In welcoming Plato to his circle of interlocutors, Socrates performed such a delegation in an epistemic sense. Plato accepted Socrates' questions as his own and so accepted this 'delegation'. ${ }^{3}$ A similar process took place between Plato and Aristotle. The mutual acceptance of the nomination, that is, nomination as master and nomination as disciple, is the condition for an epistemic authority relationship in the narrow sense. The equivalent of deontic authority directives are questions formulated by the epistemic authority. The central axis of the relations between Socrates and Plato, on the one hand, and Plato and Aristotle, on the other, are philosophical questions. Therefore, we must formulate the following thesis to complete the logic of authority:

A.1. The epistemic authority of the master includes not only statements but also questions.

This is where the fundamental difference between delegating deontic authority and the master becomes apparent. The master-disciple relation is described in the literature as a direct relation; hence, it is not possible to delegate it through an act of nomination. From this, it can be concluded that the authority of the master is not deontic but of a different kind, because he or she does not nominate delegates, but asks them questions. The value of questions lies primarily in the fact that a question, once well posed, crystallises research interests in a particular discipline of knowledge. One could say that it has a formative function, that is, it creates a scientific discipline. Hence the notion of epistemic authority should necessarily be enriched by the inheritance of questions which, once formulated, inspire subsequent generations to search.

Another difference becomes visible when we consider the position of the delegate. According to Bocheński, a delegate does not have to accept delegation (Bocheński, 1974, p. 96). The situation is different in the case of the master-disciple relation, where the student must consciously and directly accept the master as the master and an authority. This leads to the conclusion that apart from epistemic authority, the master must have authority of a different nature than deontic. We have called this kind of authority axiological authority, and its basic properties are discussed below.

Referring to the phenomenology of the authority of the master presented above, the following theses on the master-disciple relation can be formulated. One should start by referring to Bocheński's logic of authority and develop his claim 4.2-preserving its importance-in the following way:

\footnotetext{
3 The history of philosophy shows that the delegation of epistemic authority requires accepting the additional condition that its communication must be explicitly accepted (vernommen). Similar conclusions can be found in Adolf Reinach's concepts of "soziale Akte" or Paul Grice's meaningful communication.
} 


\section{A.2. Any authority is axiological authority.}

Axiological authority is vested in both epistemic authority and deontic authority. The difference amounts to the type of values guiding a given type. Axiological epistemic authority refers to the value of truth, and therefore, it is vested in those people who know a particular field better than we do, for example, the authority of a scientist for his or her students. On the other hand, deontic authority does not refer to truth, although it is desirable that it should respect this value. Rather, it refers to other values, such as goodness, happiness, justice, etc., and so it is not a concern of the scientist. Axiological deontic authority is, therefore, not the authority of a person who knows better, but of one who has the power and the right to give directives. Thus, axiological authority is not restricted to either of the aforementioned types of authority: epistemic or deontic. It comprises universal values which include, above all, truth, but also goodness, happiness, justice and others. However, a detailed axiology of authority would still have to be elaborated, as this subject is beyond the scope of this article.

We are interested in the master-disciple relation understood as a collection of true propositions. Both the master and the student strive to know the truth, but the master is more advanced in this aspiration, for instance, because of age, education, experience, etc. It can therefore be concluded that:

\section{A.3. The authority of the master is epistemic authority for the student.}

Therefore, all Bocheński's statements concerning epistemic authority and the ways of justifying it, as well as those concerning rationalism as a rejection of epistemic authority (theses 5.1-6.8), ${ }^{4}$ should be regarded as applicable.

In Bocheński's terms, the master's authority is based on a three-part relation between the bearer, the subject and the domain of authority. The bearer is the master with authority; the subject of the master's authority is another person, i.e. the student. Because in real life the relations of authority, including the master's authority, are interchangeable, i.e. the bearer of authority may become its subject and vice versa, the third term, the domain of the master's authority, is important. It is usually narrow-for example, a thesis supervisor for a doctoral student in a specific field, discipline and scientific specialty, or a master bricklayer for a student assistant bricklayer. In the case of the master's authority, Bocheński's claim that every human authority is limited to a certain domain is confirmed (Bocheński, 1974, p. 23). Reservations that remain refer to the fact that the master's authority in the narrow sense of the term is time-bound, as shown in the examples above, that is, the relation of authority builds in time and most often does not last forever.

As the bearer of authority, the master becomes an authority in a given field for the subject of authority when the subject (a student) in principle recognises whatever the bearer says as true, provided that it belongs to this domain. This does not exclude the possibility of a mistake on the part of the master, which may befall even

\footnotetext{
${ }^{4}$ Bocheński believes that rationalism is based only on reason which, just as according to Descartes, achieves the ideae clarae et distinctae by its means. Therefore, Bocheński considers that rationalism consists in not respecting any other authority. His extreme position towards rationalism stems from his AntiEnlightenment stance (Kubalica 2020, p. 57).
} 
the best authority. Infallibility is not an important feature of the master, but the inability to admit error excludes the possibility of becoming an authority. The indispensable feature of the master is, firstly, being recognised as an authoritative master; therefore, with regard to the master, the general definition of authority proposed by Bocheński remains valid:

Satz 1.3: $T$ ist eine Autorität für $S$ im Gebiet $G$ genau dann, wenn $S$ prinzipiell alles, was ihm von $\mathrm{T}$ mit Behauptung mitgeteilt wird und zum Gebiet $\mathrm{G}$ gehört, anerkennt.

[T is an authority for $\mathrm{S}$ in the domain $\mathrm{G}$ if and only if $\mathrm{S}$ in principle accepts everything that $\mathrm{T}$ assertively communicates to him and belongs to the domain $\mathrm{G}$.].

(Bocheński, 1974, p. 25)

The pragmatic situation described by Bocheński assumes that the necessary condition for the master's authority is potential - although not necessarily actual - communication, which means that the master remains an authority even if we are not interested in what he or she announces. A master is a master even when no disciple currently recognises him. For a master to exist, it is sufficient that the subject of authority can take note of what the bearer of authority says, accepting the content of the message as true. The seven factors mentioned by Bocheński, which logically assume the communication of authority, also correspond to the communication of the authority of the master. I also assume that the questions that the master poses to him or herself and the student can undeniably be included in the area of communication from the master.

When analysing the domain of authority, Bocheński considers its two meanings (often interrelated): (1) a class, a plurality of real events (activities, actions) and (2) a set of such events in the form of a set of directives (propositions) about them. Due to the fact that authority functions in the area of communication, Bocheński opts for the latter meaning (Bocheński, 1974, p. 28). Consequently, the domain of authority consists of unreal objects, since it is about communicating information, including questions, which are not real but ideal objects. It is important, however, that information or questions do not consist merely of the words which form sentences in a message, because it does not convey just words or their meanings. The same message can be conveyed using words in other languages. Therefore, the domain of authority is not limited to words alone. Information is something immaterial, spiritual and mental; it is a thought in the sense that the bearer of authority must always think something when uttering a sentence. Yet what the authority communicates (within the domain of authority) is not the thought itself, but its content (Bocheński, 1974 , p. 29). Therefore, the domain of the master's authority is not real either; it is ideal (2.1). Just as in the case of authority understood broadly, the domain of the master's authority is not a single piece of information or a single item of content (e.g. a sentence taken out of context), but a class, i.e. a collection of ideal objects (2.2). This set includes not only affirmative sentences but also questions for which specific knowledge is the basis.

In the master-disciple relation, there are also requirements concerning the subject of authority, such as being a conscious individual (2.3). In order to understand a sign and its meaning, one has to be aware of it (Bocheński, 1974, p. 30). This means 
that artificial intelligence, such as a computer, cannot be the subject of authority because, although it is capable of receiving messages, this ability depends on a specific programme designed by conscious individuals. Moreover, in normal circumstances, the master's authority is an individual matter (2.4), even though it applies also to psychosocial phenomena. Bocheński gives an example of the herd instinct and blind imitation occurring when an order is carried out uncritically, as in the Stanford Prison Experiment. This is a unique situation of 'emotional infectiousness', with a mass of people thinking like a single individual.

Nowhere else is thesis 2.6 more applicable than in the case of the master: the bearer of authority is a human being and not a group of people. There are no collegial masters. Of course, one can talk about the authority of a group, e.g. the doctors' council, but this can easily be reduced to the authority of individual members (Bocheński, 1974, p. 32). This applies even to a group organised into a committee or a think tank. The condition for the subject of authority is consciousness, which is always individual; it belongs to a single person and not to a group. Admittedly, looking from another perspective at the history of philosophy, we find collective formations practising philosophical activity, for example, Plato's Academy, Aristotle's Lyceum, the Southwest or Marburg School of Neo-Kantianism and others. While in these kinds of formations, a vital role is played by the master, who is a person, the collective plays a not insignificant role too, which in some sense amplifies the influence of the master. However, the question of how this happens goes beyond the logic of authority.

In principle, we must agree that authority in philosophy is always individual, but the degree of commonality of views in philosophical groups is different. An exception is the authority that Pythagoras enjoyed in the Pythagorean sect (Krokiewicz, 2000, p. 93). In the Pythagorean community, one can see the highest degree of consensus expressed in the use of the name of the founder of the community (Pythagorean) for all views of its members. The history of the Pythagorean sect, however, is an extreme example and should be treated as a boundary point marking the whole spectrum of possibilities for shaping relations of authority. A lesser degree of consistency can be found in Plato's or Aristotle's schools, where the founders personally supervised investigations.

At this point, one may ask what follows from the general properties of authority as a binary relation-contained in the tertiary relation of authority-between the bearer and the subject. According to thesis 3.1, no one is an authority for oneself in any field; similarly, no master is a master for him or herself. The relation of the authority of the master is thus irreflexive.

Moreover, in the relation of the master's authority, it is also logically possible that $\mathrm{T}$ is the bearer and $\mathrm{S}$ the subject of authority in one field, and at the same time, $\mathrm{T}$ is the subject and $\mathrm{S}$ the bearer of authority in another (3.2). This means that the master's bearer-subject relation is not asymmetric (Bocheński, 1974, p. 39). A master in one domain can be a disciple in another domain of knowledge, with his or her student appearing on this latter occasion as a master.

In the group of philosophers discussed above, it is not easy to show an example of a non-asymmetric relation. Nevertheless, one should agree with Bocheński, who clarifies the essence of the master's authority in thesis 3.3 in the following way: 
Ist T eine Autorität für $\mathrm{S}$ im Gebiet $\mathrm{G}$, dann ist $\mathrm{S}$ keine Autorität für T in G.

[If $\mathrm{T}$ is the authority for $\mathrm{S}$ in domain $\mathrm{G}$, then $\mathrm{S}$ is not the authority for $\mathrm{T}$ in domain G.]. (Bocheński, 1974, p. 40)

This means that authority (or, to be precise, the bearer-subject relation) is an asymmetrical relation within one field. The above statement reflects the current state of the relation and does not rule out the possibility that these roles may change, and that after some time, the relation may be reversed, with the student superseding the master. Rarely, however, does the master recognise that he or she has been superseded. The relation between Heinrich Rickert and Emil Lask can be cited as such an example. After Lask's death, Rickert explicitly admitted that, on many points, his disciple had been right and had outdone him (Rickert, 2018, pp. 11-18). The example given confirms Bocheński's thesis. Rickert recognised Lask's epistemic authority only after his death, so it is difficult to speak of an authority relation in the narrow sense (that is, between living persons). Hence, it is not true that the relationship of epistemic authority in domain $\mathrm{G}$ is not asymmetric if it is considered at a given point in time.

Another characteristic of the relation of authority is its transitive nature. At this point, the question should be asked: is the authority of the master a transitive relation? In Bocheński's view, it is not transitive if two different domains are involved:

Ist A eine Autorität für B im Gebiet $\mathrm{G}$ und $\mathrm{B}$ für $\mathrm{C}$ im selben, dann ist auch $\mathrm{A}$ eine Autorität für $\mathrm{C}$ in $\mathrm{G}$

[If $\mathrm{A}$ is an authority for $\mathrm{B}$ in domain $\mathrm{G}$, and $\mathrm{B}$ is the same for $\mathrm{C}$, then $\mathrm{A}$ is also an authority for $\mathrm{C}$ in domain $\mathrm{G}]$. (Bocheński, 1974, p. 42; 3.4)

It can therefore be concluded that an authority for an authority is also an authority for the subject provided that the field does not change: the bearer-subject relation of authority is transitive when it comes to the same domain (Bocheński, 1974, p- 41). The same applies to a master's authority: the master for the master is the master for the student in the same domain. Transitivity of the authority relation can be observed in the relation between Fries and Nelson when we include a third figure, Kant, who is an authority in the domain of philosophy for both philosophers. It can therefore be said that, if Kant is an authority for Fries in the field of philosophy, and Fries is the same for Nelson, then Kant is also an authority for Nelson in the field of philosophy. In this case, we cannot speak of authority relations in the narrow sense, since the three philosophers never met in real life. However, if we adopt a broader understanding of authority as a timeless influence, it should be considered to confirm Bocheński's thesis. Hence, it is not true that the epistemic authority relation in domain $\mathrm{G}$ is not transitive.

To recapitulate, the relation of the authority of the master is also a bearer-subject relationship and is (1) irreflexive, (2) asymmetric and (3) transitive, with the latter two being limited to the same domain (Bocheński, 1974, p. 42). Bocheński believes that these properties of authority are a necessary condition for the possibility of hierarchy and delegation of authority. These qualities are the formal characteristics of the authority of the master. 
Is there any authority of the master extending to all domains? Bocheński believes that there is no, and there cannot be, absolute human authority (Bocheński, 1974, p. 44). Recognition of absolute human authority is based on harmful mythologies, such as fascist or communist totalitarianism. The point is that everyone has authority in at least one domain, even a child who certainly knows better than anyone else whether his stomach hurts. The example Bocheński gives of a child's authority makes it possible not only to reject totalitarianism, but also to refute a radically anti-authoritarian rationalistic and anarchist mythology, whose representatives claim that there is no authority at all. Bocheński takes an intermediate position between accepting the existence of human absolute authority (totalitarianism) and the total rejection of all authority (rationalism). Bocheński's conclusions find confirmation in the history of philosophy. The history of philosophy presents examples of classical philosophical authorities, but there is no absolute authority among them. In the example of Plato-Aristotle, we see very clearly the boundary of the master's authority, which corresponds to the Latin phrase: amicus Plato, sed magis amica veritas, which is a paraphrase of both Aristotle's and Plato's views (Guerlac, 1978, p. 627). Plato was not an absolute but partial authority for Aristotle. The limited nature of authority means that he was an authority to him only insofar as his teachings were consistent with the values they both professed, above all, with truth.

Also in the case of the master-disciple relation, the master has no absolute authority; his or her authority is limited to a specific domain. Absolute authority attributed to a human being or a group of people amounts to idolatry of a very bad kind (Bocheński, 1974, p. 45). Violating this principle is an abuse of authority. Bocheński clearly states that there are two different types of authority abuse: (a) abuse of authority in a certain domain, e.g. a scientist making political statements and (b) abuse of the subject, e.g. an officer issuing orders to civilians (Bocheński, 1974, p. 45) The problem is that, in connection with thesis 1.3, it is difficult to distinguish between abuse of authority and true authority. Therefore, Bocheński introduces a new concept of justified authority stipulating that:

Was aber eine Begründung der Autorität ist, läßt sich im allgemeinen nicht sagen: die Begründung ist nämlich nach der Art der Autorität sehr verschieden.

[What justifies authority cannot be said in general, because the justification depends on the type of authority]. (Bocheński, 1974, p. 46)

The justification of the authority of the master sets the limit beyond which abuse of authority takes place. Bocheński states that:

Der Träger einer Autorität mißbraucht sie, wenn er sie in Hinblick auf ein Subjekt oder auf ein Gebiet auszuüben versucht, für bzw. in welchem seine Autorität unbegründet ist.

[The bearer of authority abuses it if he attempts to exercise it in respect to a subject or to a domain where his authority is unjustifiable]. (Bocheński, 1974, p. 46; 3.9) 
According to Bocheński, abuse results from an unjustified generalisation of authority based on the classic sophism ab uno disce omnes (generalisation). In logical terms, victims of this error silently assume that the bearer is more intelligent, more powerful, etc. than the subject, and that he or she must also have an advantage over them in other domains (Bocheński, 1974, p. 47). From a psychological point of view, in turn, the recognition of a false authority results from the habit of looking up to a person as the bearer of authority, which in some cases turns into an automatic reaction, with the subject responding uncritically and without reflection (Bocheński, 1974, pp. 47-48). The most frequent abuse of authority concerns the epistemic type of authority; hence, it also applies to the authority of the master.

Referring to Bocheński's distinctions, it can be assumed that, for the student, the personality-forming function determined by the master-disciple relation consists in the student gaining maturity and the status of a subject thanks to the influence of the master's authority. In other words, the master-disciple relation is formative in that it contributes to the formation of a subject: Thanks to the influence of the master's authority, the student gains his or her own personality. Unlike an individual or an instance of a class, the term 'person' does not reduce a human being to a purely physical or biological existence but treats him or her as the subject and the object of human relations. One of the basic characteristics of the person is self-awareness, which, as a key to self-control, is the principal tool for personal development. The influence of the master's authority does not limit but supports the self-awareness of the person, so that he or she can strive for his or her own perfection.

Another issue is related to the definition of the field of epistemic authority, which is a class of propositions. The point is that the master-disciple relation implies not only a transfer of knowledge itself, but also a transfer of a certain problem area, which is expressed in questions. Following the master, the student considers some of them important and undertakes work to find the answers. Bocheński's approach does not implement erotetic logic, which does not mean that such an application is not possible.

This article has attempted to apply the logic of authority to the history of philosophy concerning master-student relations. Bocheński's view is confronted with Stróżewski's phenomenology of authority. The approach taken here may be criticised for not growing out of the analytical perspective of Bocheński's methodology but out of the phenomenological perspective. This criticism would be justified if the article aimed to analyse the concept of authority itself. In contrast, the aim of this article has been to confront this notion with the history of philosophy. It is only against this background that Bocheński's approach turns out to be correct, and only within the limits set by the analytical method. In Bocheński's considerations, it is difficult to find a claim that his analysis is exhaustive.

In fact, Bocheński presents only necessary, but not sufficient, conditions for the possibility of authority, and he expressis verbis sets himself apart from psychological and sociological approaches. I am convinced that Stróżewski's phenomenological and axiological perspective can serve as a good point of reference, since he, too, studies the essence independent of detailed sciences. Stróżewski points to axiological features of the authority relation, such as the transfer of the hierarchy of values professed by the master and the reference to the value of 
truth. He reveals the axiological dimension of the master's authority and, at the same time, shows the dynamics of the master-student relation, which is missing in Bocheński's analytical approach.

Before closing, I would like to include a short summary here. In my opinion, the pure logic of epistemic authority is not enough to describe the master-disciple relation in the field of philosophy. The primary limitation is that this logic does not reflect the dynamics of the authority relationship. It is hard to understand this dynamic without taking into account the questions that have been asked and the answers that have been offered by the master. Another component is necessary to complete the picture, which I call axiological authority. The master-student relation is also a community of specific values. Only the adoption of similar values allows for the assumption that the master is an epistemic authority for the student.

In conclusion, I would like to add that this article certainly does exhaust the issue of the relationship of authority in the history of philosophy. It is not easy to cover all the diversity in this field, and that is why I concentrated on the most classical accounts known from many handbooks on the history of philosophy. However, this means that there is a need for further research to better understand the influence of authorities on the development of philosophical thought and to avoid a selective approach focused only on some of the personalities in the history of philosophy.

Acknowledgements This paper was made possible thanks to the help of numerous friends to whom I am indebted. I am especially grateful to the participants of the seminar conducted by Andrzej J. Noras, with special thanks for stimulating comments, valuable hints, and support. I would like to thank Krystyna Warchał for the proofreading and many hard linguistic corrections. I am very grateful to Edward Świderski and Anna Brożek for their careful reading of the text and many valuable comments and corrections.

Open Access This article is licensed under a Creative Commons Attribution 4.0 International License, which permits use, sharing, adaptation, distribution and reproduction in any medium or format, as long as you give appropriate credit to the original author(s) and the source, provide a link to the Creative Commons licence, and indicate if changes were made. The images or other third party material in this article are included in the article's Creative Commons licence, unless indicated otherwise in a credit line to the material. If material is not included in the article's Creative Commons licence and your intended use is not permitted by statutory regulation or exceeds the permitted use, you will need to obtain permission directly from the copyright holder. To view a copy of this licence, visit http://creativecommons.org/licen ses/by/4.0/.

\section{References}

Bocheński, J. M. (1974). Was ist Autorität? Einführung in die Logik der Autorität. Freiburg: Verlag Herder.

Brożek, A. (2013). Bocheński on authority. Studies in East European Thought, 65(1), 115-133. https:// doi.org/10.1007/s11212-013-9175-9

Copleston, F. (1994). A History of Philosophy. Volume 4. Modern Philosophy. From Descartes to Leibniz (8th ed., Vol. 4). New York: Image Books, Doubleday.

Gogacz, M. (1964). W sprawie koncepcji historii filozofii. Zeszyty naukowe KUL, (3 (27)), 53-57.

Gogacz, M. (1966). O pojęciu i metodzie historii filozofii. Ruch filozoficzny, (25/1), 70-80. 
Guerlac, H. (1978). Amicus Plato and other friends. Journal of the History of Ideas, 39(4), 627. https:// doi.org/10.2307/2709446

Kraut, R. (Ed.). (2006). The Cambridge Companion to Plato. Cambridge: Cambridge University Press. https://doi.org/10.1017/CCOL0521430186

Krokiewicz, A. (2000). Zarys filozofii greckiej. Warszawa: Aletheia.

Kubalica, T. (2015). Różne znaczenia szkoły w filozofii a neokantyzm Leonarda Nelsona. Folia Philosophica, 33, 51-70.

Kubalica, T. (2019). Hermann Cohen i Ernst Cassirer w relacji mistrz-uczeń. Studia Philosophica Wratislaviensia, 14(3), 69-80. http://dx.doi.org/https://doi.org/10.19195/1895-8001.14.3.5

Kubalica, T. (2020). Kontrowersje wokół autorytetu w świetle analiz Józefa M. Bocheńskiego na tle współczesnej recepcji idei Oświecenia. Ruch Filozoficzny, 76(3), 53-71. https://doi.org/10.12775/ RF.2020.034

Rickert, H. (2018). Der Gegenstand der Erkenntnis. Historisch-kritische Ausgabe. Teil 2: 6. Auflage (1928). 3. und 4./5. Auflage durch editorischen Apparat. (R. A. Bast, Ed.) (Vol. 2/2). Berlin, Boston: De Gruyter. https://doi.org/10.1515/9783110567830

Ross, W. D. (2004). Aristotle. (J. L. Ackrill, Ed.) (6th ed.). London: Routledge.

Stróżewski, W. (1992). Mała fenomenologia autorytetu. In W kręgu wartości (pp. 27-32). Kraków: Znak. Stróżewski, W. (1996). Dwaj mistrzowie. In Mistrz i uczeń. Materiały z sympozjum 18-19 marca 1996 Kraków (pp. 23-33). Kraków: Bratnia Pomoc Akademicka im. św. Jana z Kęt „Cantianum”.

Swieżawski, S. (2005). Zagadnienie historii filozofii (2nd ed.). Warszawa: Semper.

Publisher's Note Springer Nature remains neutral with regard to jurisdictional claims in published maps and institutional affiliations. 